\title{
PENYELESAIAN SENGKETA BISNIS MELALUI ALTERNATIVE DISPUTE RESOLUTION (ADR)
}

\author{
OLEH : \\ JOKO NUR SARIONO \\ AGUS DONO WIBAWANTO
}

\begin{abstract}
$A D R$ represent alternative of solving of extrajudical done law dispute that is passing process of negonisasi and of mediasi and of abitrase for the process of and negonisasi of mediasi represent process of [is solving of dispute compromisely with result of trouble-shooting with while abitrasi represent process of solving of dispute by compromise of negonisasi compete which decision have the character of final.
\end{abstract}

Keyword : solving of dispute, compromise, extrajudical.

\section{PENDAHULUHAN}

Salah satu ciri bisnis atau perekonomianan yang paling menonjol pada era globalisasi adalah moving quickly. Perubahan dan pergeseran yang cepat dalam era super industrialis sekarang telah mengantar umat manusia ke suatu kehidupan "dunia tanpa batas" (borderless world) (Keinichi Ohmae, Bordeless World, Harper Business (Printed in USA : Maknisey Company Inc. 1990) : 12). Keadaan ini digambarkan John Naisbitt (Lihat John Naisbitt, Megatrend 2000, Pan Books (Publised in Great Britain : Sidgwick \& Jackson Ltd. 1990) : 2) sebagai perubahan yang dihadapi manusia. Dunia yang dihuni manusia telah berubah menjadi global village (perkampungan global) dengan sistem perekonomian single economy. "The World moving from trade countries to a single economy. One economy. One market place."

Mengamati kegiatan bisnis yang jumlah transaksinya ratusan setiap hari, tidak mungkin dihindari terjadinya sengketa (dispute/difference) antar pihak yang terlibat. Setiap jenis sengketa yang terjadi selalu menuntut pemecahan dan penyelesaian yang cepat. Makin banyak yang luas kegiatan perdagangan, frekuensi terjadinya sengketa makin tinggi. Ini berarti makin banyak sengketa yang harus diselesaikan.
Penyelesaian Sengketa Bisnis Melalui Alternative Dispute Resolution (adr) 
Membiarkan sengketa dagang terhambat diselesaikan akan mengakibatkan perkembangan pembangunan ekonomi tidak efisien, produktivitas menurun, dunia bisnis mengalami kemandirian, dan biaya produksi meningkat. Konsumen adalah pihak yang paling dirugikan. Disamping itu, peningkatan kesejahteraan dan kemajuan sosial kaum pekerja juga terhambat

Secara konvensional, penyelesaian sengketa biasanya dilakukan secara litigasi atau penyelesaian sengketa di muka pengadilan. Dalam keadaan demikian, posisi para pihak yang bersengketa sangat antagonistis (saling berlawanan satu sama lain).

Penyelesaian sengketa bisnis model ini tidak direkomendasikan. Kalaupun akhirnya ditempuh, penyelesaian itu semata-mata hanya sebagai jalan yang terakhir (ultimatum remedium) setelah alternatif lain dinilai tidak membuahkan hasil.

Proses penyelesaian sengketa yang mem-butuhkan waktu yang lama mengakibatkan perusahaan atau para pihak yang bersengketa mengalami ketidak-pastian. Cara penyelesaian seperti itu tidak diterima dunia bisnis karena tidak sesuai dengan tuntutan zaman. Penyelesaian sengketa bisnis melalui lembaga peradilan tidak selalu menguntungkan secara adil bagi kepentingan para pihak yang bersengketa.

Sehubungan dengan uraian tersebut di atas, cara dan sistem penyelesaian sengketa bisnis yang cepat, efektif, dan efisien. Untuk itu harus dibina dan diwujudkan suatu sistem penyelesaian sengketa bisnis yang dapat menyesuaikan diri dengan laju perkembangan perekonomian dan perdagangan di masa datang. Dalam menghadapi liberalisasi perdagangan harus ada lembaga yang dapat diterima dunia bisnis dan memiliki kemampuan system menyelesaikan sengketan dengan cepat dan biaya murah (quick and lower in time and money to the parties).

Di samping model penyelesaian sengketa secara konvensional melalui litigasi sistem peradilan (ordinary court), dalam praktek di Indonesia dikenalkan pula model yang relatif baru. Model ini cukup populer di Amerika Serikat dan Eropa yang dikenal dengan nama ADR (alternatif dispute resolution) yang diantaranya meliputi negosiasi, mediasi, dan arbitrase (Wahyu Nugroho. Penggunaan Mediasi dalam Penyelesai-
Penyelesaian Sengketa Bisnis Melalui Alternative Dispute Resolution (adr) 
an Sengketa Bisnis. News letter No. 21, Jura 1995).

Walaupun penyelesaian sengketa dapat dilakukan dengan menggunakan model ADR, namun tidak menutup peluang penyelesaian perkara tersebut secara litigasi. Penyelesaian perkara secara litigasi tetap dapat dipergunakan manakala penyelesaian secara nonlitigasi tidak membuahkan hasil. Jadi, penggunaan ADR adalah sebagai salah satu mekanisme penyelesaian sengketa nonlitigasi dengan mempertimbangkan segala bentuk efisiensinya dan untuk tujuan masa yang akan datang sekaligus menguntungkan bagi para pihak yang bersengketa. (Basuki Rekso Wibowo, 1966 : 25)

\section{Alternative Dispute Resolution (ADR)}

Sengketa biasanya bermula dari suatu situasi dimana ada pihak yang merasa dirugikan oleh pihak lain. Hal ini diawali oleh perasaan tidak puas yang bersifat subjektif dan tertutup. Kejadian ini dapat dialami oleh perorangan maupun kelompok. Perasaan tidak puas akan muncul ke permukaan apabila terjadi conflict of interest. Pihak yang merasa dirugikan akan menyampaikan ketidak- puasannya kepada pihak kedua. Apabila pihak kedua dapat menanggapi dan memuaskan pihak pertama, selesailah konflik tersebut Sebaliknya, jika reaksi dari pihak kedua menunjukkan perbedaan pendapat atau memiliki nilai-nilai yang berbeda, terjadi apa yang dinamakan dengan sengketa.

Proses sengketa terjadi karena tidak adanya titik temu antara pihak-pihak yang bersengketa. Secara potensial, dua pihak yang mempunyai pendirian /pendapat yang berbeda dapat beranjak ke situasi sengketa. Secara umum, orang tidak akan mengutarakan pendapat yang mengakibatkan konflik terbuka. Hal ini disebabkan oleh kemungkinan timbulnya konsekuensi yang tidak menyenangkan, dimana seseorang (pribadi atau sebagai wakil kelompoknya) harus menghadapi situasi rumit yang mengundang ketidaktentuan sehingga dapat mempengaruhi kedudukannya.

Dalam persengketaan, perbedaan pendapat dan perdebatan yang berkepanjangan biasanya mengakibat-kan kegagalan proses mencapai kesepakatan. Keadaan seperti ini biasanya berakhir dengan putusnya jalur komunikasi yang sehat sehingga masing-masing pihak
Penyelesaian Sengketa Bisnis Melalui Alternative Dispute Resolution (adr) 
mencari jalan keluar tanpa memikirkan nasib ataupun kepentingan pihak lainnya.

Agar tercipta proses penyelesaian sengketa yang efektif, prasyarat yang harus dipenuhi adalah kedua belah pihak harus sama-sama memperhatikan atau menjunjung tinggi hak untuk mendengar dan hak untuk didengar. Dengan prasyarat tersebut proses dialog dan pencanan titik temu (command ground) yang akan menjadi panggung proses penyelesaian sengketa baru dapat berjalan. Jika tanpa kesadaran tentang pentingnya langkah ini, proses penyelesaian sengketa tidak berjalan dalam arti yang sebenanya.

Ada 3 faktor utama yang mempengaruhi proses penyelesaian sengketa, yaitu : (William Ury, J.M. Brett, S.B. Goldberg, Getting Disputes Resolved, Pan Books. 1993)1. Kepentingan (interest), 2. Hak-hak (rights), dan 3. Status kekuasaan (power).

Para pihak yang bersengketa menginginkan agar kepentingannya tercapai, hak-haknya dipenuhi, dan kekuasaannya diperlihatkan, dimanfaatkan, dan dipertahankan. Dalam proses penyelesaian sengketa, pihak-pihak yang bersengketa lazimnya akan bersikeras mempertahankan ketiga faktor tersebut di atas.

Bila menyimak sejarah perkembangan ADR di negara tempat pertama kali dikembangkan (Amerika Serikat), pengembangan ADR dilatarbelakangi oleh kebutuhan sebagai berikut: (Stephen B. Golberg, Dispute Resolution. Little Brown and Company. 1985 : 5-7)

1. Mengurangi kemacetan di pengadilan. Banyaknya kasus yang diajukan ke pengadilan menyebabkan proses pengadilan seringkali berkepanjangan sehingga memakan biaya yang tinggi dan sering memberikan hasil yang kurang memuaskan.

2. Meningkatkan ketertiban masyarakat. dalam proses penyelesaian sengketa.

3. Memperlancar serta memperluas akses ke pengadilan.

4. Memberikan kesempatan bagi tercapainya penyelesaian sengketa yang menghasilkan keputusan yang dapat diterima oleh semua pihak dan memuaskan.

Proses penyelesaian sengketa (consesually based approaches) mengharuskan para pihak mengembangkan penyelesaian yang dapat diterima bersama. Proses ini berakar pada sistem
Penyelesaian Sengketa Bisnis Melalui Alternative Dispute Resolution (adr) 
pengaturan sendiri (self-governing system) yang dapat ditemukan di negara Indonesia.

\section{Pengertian ADR}

ADR merupakan suatu istilah asing yang perlu dicarikan padanannya dalam bahasa Indonesia. Berbagai istilah dalam bahasa Indonesia telah diperkenalkan dalam berbagai forum oleh berbagai pihak, seperti pilihan penyelesaian sengketa (PPS) (Lihat Undang-Undang No. 23 Tahun 1997 tentang Pengelolaan Lingkungan Hidup (UPLH) memperkenalkan dan memberikan sarana penyelesaian sengketa lingkungan hidup di luar pengadilan (ADR), didayagunakan, diefektifkan sebagai pilihan penyelesaian sengketa lingkungan hidup secara alternatif), mekanisme alternatif penyelesaian sengketa (MAPS) (Penggunaan istilah (MAPS) dapat diartikan pada penekanan serta pengembangan metode penyelesaian konflik bersifat kooperatif di luar pengadilan. Bandingkan Mas Achmad Santos dan Anthony LP. Hutapea, Mendayagunakan Mekanisme Alternatif Sengketa Lingkungan (MPAS) di Indonesia (Jakarta WALHI, 1992)), pilihan penyelesaian sengketa di luar pengadil-an, dan mekanisme penyelesaian sengketa secara kooperatif.

Alternative dispute resolution (ADR) sering diartikan sebagai alternative to litigation dan alternative to adjudication. Pemilihan terhadap salah satu dan dua pengertian tersebut menimbulkan implikasi yang berbeda.

Apabila pengertian pertama yang menjadi acuan (alternative to litigation), seluruh mekanisme penyelesai-an sengketa di luar pengadilan termasuk arbitrase, merupakan bagian dari ADR. Apabila ADR (di luar litigasi dan arbitrase) merupakan bagian dari ADR, pengertian ADR sebagai alternative to adjudication dapat meliputi mekanisme penyelesaian sengketa yang bersifat konsensus atau kooperatif seperti halnya negosiasi, mediasi, dan konsiliasi.

Jika kita mengamati latar belakang pengembangan ADR di Amerika Serikat, ADR yang dimaksud adalah ADR sebagai alternative to adjudication. Hal ini disebabkan keluaran (autcomey adjudication, baik pengadilan maupun arbitrase cenderung menyluisilkaii solusi "win lose", hulam "win win", seliinggu solusi yang dapat diterima kedua belah pihak
Penyelesaian Sengketa Bisnis Melalui Alternative Dispute Resolution (adr) 
yang bersengketa (mutual acceptable solution) sangat kccil dapat tercapai.

Istilah ADR memberi kesan bahwa pengembangan mekanisme penyelesaian sengketa secara konsensus hanya dapat dilakukan di luar pengadilan (out court), sedangkan saat ini dibutuhkan juga di dalam pengadilan (court annexed atau court connected), beragamnya pengertian ADR dilandasi oleh pertimbangan psikologis untuk mendapatkan dukungan terhadap penyelesaian melalui $A D R$ dari pihak pengadilan. ADR seolah-olah merupakan jawaban atas kegagalan pengadilan memberikan akses keadilan bagi masyarakat sehingga pemasyarakatan istilah ini mengundang rasa tidak aman dan kecemburuan bagi insan pengadilan.

Bila kita mengartikan ADR sebagai alternative to adjudication, padanan istilah MAPS, PPS, dan mekanisme penyelesaian sengketa secara kooperatif merupakan tiga istilah untuk dipertimbangkan sebagai padanan istilah bahasa Indonesia. Apabila ADR diartikan sebagai alternative to litigation, mekanisme arbitrage dapat dimasukkan atau digolongkan dalam kelompok $A D R$ sehingga MAPS dan PPS merupakan dua padanan istilah yang dapat dipertimbangkan. (Mas Achmad Santoso. Pelembagaan $A D R$ di Indonesia. Makalah pada Kuliah Umum ADR. Fakultas Hukum Unika Atmajaya. Jakarta. 1997 :1-2)

Istilah ADR merupakan label atau merek yang diberikan untuk mengelompokkan proses negosiasi, mediasi, konsiliasi, dan arbitrase. Masalah pilihan istjlah adalah suatu hal yang perlu dipikirkan lebih jauh. Untuk menjamin keberhasilan upaya menyebarluaskan penerapun ADR di Indonesia, diperlukan istilah yang singkat, mudah dimengerti, dan tidak menimbulkan kerancuan.

Secara teoretis, dalam bidang tenaga kerja telah diatur jalur penyelesaian sengketa yang bernafaskan suatu rangkaian kesatuan.

Istilah bipartit dan tripartit digunakan sesuai asas negosiasi, mediasi, atau konsiliasi. Undang-Undang No. 22 Tahun 1957 mengatur penggunaan arbitrase wajib melalui Panitia Penyelesaian Perselisihan Perburuhan Pusat dan Daerah (P4P/P4D) dan arbitrase sukarela yang melibatkan pihak di luar Depnaker. Undang-Undang No. 25 Tahun 1997 Pasal 71 mengatur adanya lembaga banding setelah mediasi.
Penyelesaian Sengketa Bisnis Melalui Alternative Dispute Resolution (adr) 
Lembaga tersebut adalah Lembaga Penyelesaian Perselisihan Industrial yang identik dengan lembaga P4P/P4D. Pilihan Penyelesaian Sengketa merupakan padanan yang setidaknya dianggap baku secara nasional, Hal ini terdapat dalam Undang-Undang No. 23 tahun 1997 tentang Pengelolaan Lingkungan Hidup.

\section{ADR Dalam Masyarakat Indonesia}

Sebagian besar penduduk Indonesia hidup di pedesaan. Mereka merasa dirinya sebagai bagian dari alam sekitarnya (alarn semesta). Dengan kata lain, penduduk senantiasa harus menyesuaikan perilakunya dengan tata hidup alamiah untuk mencapai kebahagiaan. Sehubungan dengan hal tersebut, mereka dalam berperilaku memperhitungkan ketentuan-ketentuan gaib yang tidak tampak.

Jika timbul sengketa diantara mereka, jarang sekali dibawa ke pengadilan negara untuk diselesaikan. Mereka lebih suka dan dengan senang hati membawa sengketa ke lembaga yang tesedia pada masyarakat adat untuk diselesaikan secara damai. Dalam masyarakat hukum adat, penyelesaian sengketa biasanya dilakukan di hadapan kepala desa atau hakim adat.

\section{Perlu disadari bahwa secara} historis, kultur masyarakat Indonesia sangat menjunjung tinggi pendekatan konsensus. Pengembangan penyelesaian sengketa di Indonesia sesuai dengan mekanisme pengambilan keputusan secara tradisional dan penyelesaian sengketa secara adat. Alasan kultural bagi eksistensi dan pengembangan ADR di Indonesia tampaknya lebih kuat dibandingkan alasan ketidakefisienan proses peradilan dalam menangani sengketa.

Di Indonesia, proses penyelesaian melalui ADR bukanlah sesuatu yang baru dalam nilai-nilai budaya bangsa kita yang berjiwa kooperatif. Nilai kooperatif dan kompromi dalam penyelesaian sengketa muncul dimana saja di Indonesia. Pada masyarakat Batak yang relatif memiliki nilai religious, masih mengandalkan forum runggun adat yang intinya penyelesaian sengketa secara musyawarah dan kekeluargaan. Di Minangkabau, dikenal adanya lembaga hakim perdamaian yang secara umum berperan sebagai mediator dan konsiliator. Konsep pembuatan keputusan dalam pertemuan desa pada suku Jawa tidak didasarkan atas suara
Penyelesaian Sengketa Bisnis Melalui Alternative Dispute Resolution (adr) 
mayoritas, tetapi dibuat oleh keseluruhan yang hadir sebagai suatu kesatuan.

\section{Pengembangan ADR Di Indonesia}

Indonesia mempunyai beragam metoda pengambilan keputusan dan penyelesaian sengketa, baik tradisional maupun metoda dari luar. Metoda ini dapat dibagi dalam 2 prosedur sebagai berikut : (Mas Achmad Santoso. Pelembagaan ADR di Indonesia. Makalah pada Kuliah Umum ADR. Fakultas Hukum Unika Atmajaya. Jakarta. 1997 : 10)

\section{a. Prosedur adminitratif atau prosedur yudisial.}

Dalam prosedur ini sanksi dari pihak ketiga dapat berupa rekomendasi atau keputusan yang mengikat. Prosedur ini berakar pada proses pengadilan pada zaman kerajaan, kesultanan, adat setempat atau pemuka adat desa, serta prosedur administratif pengadilan zaman kolonial Belanda.

\section{b. Proses konsensus sukarela (consesually-based approaches)}

Dalam proses ini para pihak mengembangkan penyelesaian yang dapat diterima bersama. Proses ini berakar dari sistem pengaturan sendiri (self-governing system) yang dapat ditemukan di negara kepulauan kita. Ada beberapa persamaan lain yang ditemukan pada masyarakat Indonesia. Pertama, banyak sengketa yang diselesaikan melalui prosedur yudisial, dimana ada otoritas dari pengambil keputusan, seperti pemuka adat yang memfasilitasi sebuah pertemuan antar pihak yang bersengketa dan membantu bernegosiasi dengan memakai standar (kriteria) adat atau kerangka penyelesaian menurut saran pemukak suku yang masih mempertahankan prosedur konsensus sukarela untuk menyelesaikan sengketa. Bentuk consensually-based dapat diartikan ke dalam bentuk musyawarah untuk mencapai mufakat (consensus).

Beberapa alasan pengembangan ADR di Indonesia selain alasan di atas dapat dilihat sebagai suatu peluang adalah sebagai berikut : (Mas Achmad Santosa dan Anthony LP. Hutapea, Mendayagunakan Mekanisme Afternalif Penyelesaian Sengketa (MAPS) di bidang Lingkungan Hidup di Indonesia. WALHI, Jakarta: 1992:2)
Penyelesaian Sengketa Bisnis Melalui Alternative Dispute Resolution (adr) 


\section{c. Faktor ekonomis}

ADR memiliki potensi sebagai sarana penyelesaian yang lebih ekonomis, baik dari sudut pandang biaya maupun waktu.

\section{d. Faktor ruang lingkup yang dibahas}

ADR memiliki kemampuan untuk membahas agenda permasalahan secara lebih luas, komprehensif, dan fleksibel. Hal ini dapat terjadi karena aturan main dikembangkan dan ditentukan oleh para pihak yang bersengketa sesuai dengan kepentingan dan kebutuhannya. ADR memiliki potensi untuk menyelesaikan konflik-konflik yang sangat rumit (polycentris) yang disebabkan oleh substansi kasus yang sarat dengan persoalan-persoalan ilmiah (scientifically complicated).

\section{e. Faktor pembinaan hubungan baik.}

ADR yang mengandalkan caracara penyelesaian kooperatif sangat cocok bagi mereka yang menekankan pentingnya pembinaan hubungan baik antar manusia yang telah berlangsung maupun yang akandatang.
Konsepsi ADR di Indonesia dalam beberapa tahun ini mendapat perhatian yang lebih karena hal-hal sebagai berikut :

a) Antisipasi perdagangan bebas. Dalam kegiatan bisnis yang ratusan jumlah transaksinya setiap hari tidak mungkin dihindari terjadinya sengketa (dispute/difference) antar pihak yang terlibat. Setiap jenis sengketa selalu menuntut pemecahan dan penyelesaian. Makin banyak terjadi sengketa, makin banyak sengketa yang hams diselesaikan.

b) Meningkatnya jumlah dan bobot sengketa di masyarakat. Membiarkan sengketa bisnis terhambat diselesaikan mengakibatkan pembangunan ekonomi tidak efisien, produktivitas menurun, dunia bisnis akan mengalami kemandulan, dan biaya produksi akan meningkat.

c) Perlu dicari dan dipikirkan cara dan sistem penyelesaian sengketa yang cepat, efektif, dan efisien. Era globlalisasi mengharuskan adanya suatu sistem penyelesaian sengketa yang dapat menyesuaikan dengan laju kecepatan perekonomian dan perdagangan menuju "free market"
Penyelesaian Sengketa Bisnis Melalui Alternative Dispute Resolution (adr) 
dan "free competition". Untuk itu harus ada lembaga yang mewadahinya.

ADR mempunyai daya tarik khusus di Indonesia karena keserasiannya dengan sistem sosial budaya tradisional berdasarkan musyawarah mufakat. Beberapa hal di bawah ini merupakan keuntungan yang sering muncul dalam ADR : (Disalin dari Cristhoper W. Moore, The Executive Seminar on Alternative Dispute Resolution Procedure, CDR Associates, Colorado : 1995 : 14)

\section{a. Sifat kesukarelaan dalam proses}

Para pihak percaya bahwa ADR memberikan jalan keluar yang potensial untuk menyelesaikan masalah dengan lebih baik dibandingkan dengan prosedur litigasi dan prosedur lainnya yang melibatkan para pembuat keputusan dari pihak ketiga. Secara umum, tidak seorangpun dipaksa untuk menggunakan prosedur-prosedur ADR.

\section{b. Prosedur yang cepat}

Karena prosedur ADR bersifat informal, pihak-pihak terjibat mampu untuk menegosiasikan syarat-syarat penggunaannya. Hal ini mencegah terjadinya penundaan dan mempercepat proses penyelesaian. Produktivitas menurun, dunia bisnis akan mengalami kemandulan, dan biaya produksi akan meningkat.

\section{c. Keputusan non yudisial}

Wewenang untuk membuat keputusan tetap berada pada pihak-pihak yang terlibat atau tidak didelegasikan kepada pembuat keputusan dari pihak ketiga. Hal ini berarti bahwa pihak-pihak terlibat mempunyai lebih banyak kontrol terhadap hasil-hasil sengketa dan mampu meramalkan.

\section{d. Kontrol tentang kebutuhan organisasi}

Prosedur ADR menempatkan keputusan di tangan orang yang mempunyai posisi tertentu (penting), baik untuk menafsirkan tujuan-tujuan jangka panjang dan jangka pendek dari organisasi yang terlibat maupun menafsirkan dampak-dampak ppsitif dan negatif dari setiap pilihan penyelesaian masalah tertentu. Pihak ketiga dalam membuat keputusan yang mengikat suatu isu sering 
kali meminta bantuan sebrang hakim, juri, atau arbiter.

\section{e. Prosedur rahasia (confidental}

Prosedur ADR memberikan jaminan kerahasiaan bagi para pihak dengan porsi yang sama. Pihak-pihak dapat menjajaki pilihan-pilihan sengketa yang potensial dan hak-hak mereka dalam mempresentasikan data untuk menyerang halik tetap dilindungi.

\section{f. Fleksibilitas}

Dalam merancang syarat-syarat penyelesaian masalah Prosedur MAPS memberikan fleksibilitas yang lebih besar bagi parameter-parameter isu yang sedang didiskusikan dan cakupan dari penyelesaian masalah. Disamping itu, memungkinkan pengembangan cara penyelesaian yang lebih komprehensif untuk membahas penyebab persengketaan.

Prosedur ini dapat menghindari kendala prosedur yudisial yang sangat terbatas pada pembuatan keputusan pengadilan yang didasarkan pada titik sempit hukum, seperti apakah prosedur yang resmi sudah diikuti atau belum.

\section{g. Hemat waktu}

Selama ini proses penyelesaian masalah sering mengalami kelambatan yang cukup berarti dalam menunggu kepastian tanggal persidangan. Prosedur ADR menawarkan kesempatan yang lebih cepat untuk menyelesaikan sengketa tanpa harus menghabiskan waktu bertahun-tahun untuk melakukan litigasi. Dalam banyak hak, waktu adalah uang dan penundaan penyelesaian masalah memerlukan biaya yang sangat mahal. Penyelesaian sengketa yang dikembangkan melalui penggunaan prosedur ADR merupakan alternatif penyelesaian masalah yang tepat.

\section{h. Hemat biaya}

Besarnya biaya biasanya ditentukan oleh lamanya waktu yang dipergunakan. Pihak ketiga yang netral rata-rata memasang tarif yang lebih rendah untuk mengganti waktu mereka dibandingkan apabila membayar para pengacara hukum.

\section{i. Pemeliharaan hubungan}

ADR menghasilkan kesepakatankesepakatan yang dinegosiasikan dengan memperhatikan kebutuhan-
Penyelesaian Sengketa Bisnis Melalui

Alternative Dispute Resolution (adr) 
kebutuhan pihak-pihak terlibat. Dengan kata lain, ADR mampu mempertahankan hubungan-hubungan kerja yang sedang berjalan maupun untuk masa mendatang.

\section{j. Tingginya kemungkinan untuk melaksanakan kesepakatan}

Dalam ADR, para pihak yang telah mencapai kesepakatan cenderung untuk memenuhi syarat-syarat atau isi kesepakatan yang telah ditentukan oleh pengambil keputusan (pihak ketiga). Faktor ini membantu para pihak yang terlibat untuk menghindari litigasi yang tidak efektif.

\section{k. Kontrol dan lebih mudah mem- perkirakan hasil.}

Pihak-pihak yang menegosiasikan sendiri penyelesaian sengketanya mempunyai lebih banyak kontrol terhadap hasil-hasil penyelesaian sengketa. Cara penyelesaian melalui negosiasi atau mediasi lebih mudah memperkirakan keuntungan dan kerugian dibandingkan jika kasus tersebut diselesaikan melalui arbitrase atau di depan seorang hakim

\section{Keputusan bertahan sepanjang waktu.}
Keputusan penyelesaian sengketa dengan prosedur ADR cenderung bertahan sepanjang waktu. Jika di kemudian hari persengketaan itu menimbulkan masalah, pihak-pihak terlibat lebih memanfaatkan bentuk pemecahan masalah yang kooperatif dibandingkan menerapkan pendekatan adversial atau pertentangan.

Dalam pelaksanaan sistem peradilan di Indonesia, gagalnya komunitas hukum untuk melakukan penyelesaian sengketa dengan cepat adalah salah satu penyebab terjadinya penumpukan perkara (congestion) didalam sistem peradilan perdata (civil justice system). Sehubungan dengan hal tersebut, pengembangan mekanisme penyelesaian sengketa secara kooperatif memiliki potensi yang layak dikembangkan dan didayagunakan di dalam pengadilan.

\section{PENUTUP}

ADR merupakan altematif penyelesaian sengketa yang dilakukan di
Penyelesaian Sengketa Bisnis Melalui Alternative Dispute Resolution (adr) 
luar pengadilan (ordinary court) melalui proses negosiasi, mediasi, dan arbitrase. Negosiasi dan mediasi merupakan bagian dan proses penyelesaian sengketa secara kompromi (kooperatif antar pihak) dengan tujuan pemecahan masalah bersama. Dalam arbitrase, proses penyelesaian sengketanya disebut "metode kompromi negosiasi bersaing", dan terdapat pihak ketiga yang putusannya bersifal final.

\section{DAFTAR PUSTAKA}

Basuki Rekso Wibowo. Studi Perbandingan Beberapa Model Alternatif Penyelesaian Sengketa Bisnis. Pro Justitia No. 4, Tahun 16, Oktober 1966.

Disalin dari C,risthoper W. Moore, The Executive Seminar on Alternative Dispute Resolution Procedure, CDR Associates, Colorado : 1995.

Keinichi Ohmae, Bordeless World, Harper Business. Printed in USA : Maknisey; Company Inc. 1990,

Lihat John Naisbitt, Megatrend 2000, Pan Books, Publised in Great Britain : Sidgwick \& Jackson Ltd. 1990.
Lihat Undang-Undang No. 23 Tahun 1997 tentang Pengelolaan Lingkungan Hidup (UPLH) memperkenalkan dan memberikan sarana penyelesaian sengketa lingkungan hidup di luar p e ng adilan (ADR), didayagunakan, diefektifkan sebagai pilihan penyelesaian sengketa lingkungan hidup secara alternatif.

Mas Achmad Santoso. Pelembagaan ADR di Indonesia. Makalah pada Kuliah Umum ADR. Fakultas Hukum Unika Atmajaya. Jakarta. 1997.

Mas Achmad Santosa dan Anthony LP. Hutapea, Mendayagunakan Mekanisme Afternalif Penyelesaian Sengketa (MAPS) di bidang Lingkungan Hidup di Indonesia. WALHI, Jakarta : 1992.

Penggunaan istilah (MAPS) dapat diartikan pada penekanan serta pengembangan metode penyelesaian konflik bersifat kooperatif di luar pengadilan. Bandingkan Mas Achmad Santos dan Anthony LP. Hutapea, Mendayagunakan Mekanisme Alternatif Sengketa Lingkungan (MPAS) di Indonesia (Jakarta WALHI, 1992).

Stephen B. Golberg, Dispute Resolution. Little Brown and Company. 1985.
Penyelesaian Sengketa Bisnis Melalui Alternative Dispute Resolution (adr) 